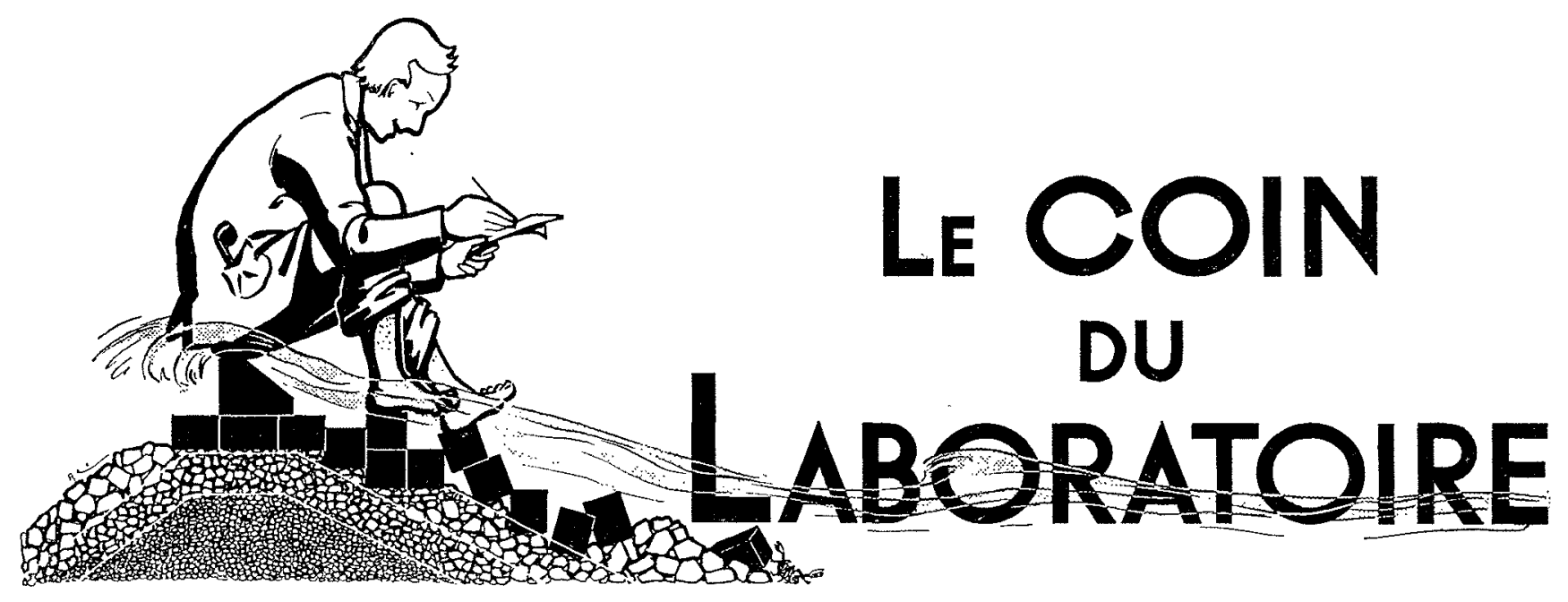

\title{
Contribution à la mesure de pression différentielle
}

\author{
A contribution \\ to differential pressure measurement
}

\begin{abstract}
On peut mesurer la pression d'eau différentielle au moyen de n'importe quel instrument détecteur sensible pouvant mesurer la pression de l'air, si l'on applique la méthode de mesure en deux stades, ce qui permel d'utiliser l'air comme agent transmelteur de pression. En changeant lu dimension de quelques parties de l'installation, on peut ítendre largement la gamme des mestures. Nous présentons ici quelques résultuts obtenus pour des vitesses allant jusqu'à $1 \mathrm{~cm} / \mathrm{s}$.
\end{abstract}

La mesure de la pression d'eau différentielle se heurte à certaines difficultés, qui peurent soit influer sur la rapidité des opérations de mesures, soit altérer la nature des résultats, soit encore, dans cerlains cas, rendre impraticables les méthodes différentielles.

Premierement, les prises de pression et les instruments indiquant la hauteur différentielle sont

\begin{abstract}
Differential pressure of water can be measured by means of any adequately sensitive air-pressure deterting apparatus, if a two-step measuring technique is employed, which renders possible the use of air as pressure transmitting medium. By varying the size of some pertinent parts of the arrangement, measurements can be extended over a wide range. Some results with belocities down $101 \mathrm{~cm} / \mathrm{sec}$ are presented.
\end{abstract}

The measuring of differential pressure of water meets with certain difficulties, which either affect the promptness of the measuring procedure, impair the reliability of the results, or, in some situalions, render differential methode impraticab!e.

First, the pressure lappings and the differential head indicaling instruments are somelimes 
parfois reliés par des tuyaux flexibles remplis d'eau et assez longs, dont le remplissage doit être effectué avec le plus grand soin si l'on veut enlever completement toute trace d'air. Toutefois, dans le cas d'une utilisation prolongée de l'installation, l'air peut s'infiltrer à nouveau dans certaines parties de l'instrument.

Deuxièmement, des mouvements oscillatoires de la colonne d'eau dans les tuyaux, provoqués par les variations de pression dans le courant d'eau, peuvent créer des difficultés pour la mesure.

Troisièmement, les manomètres à deux liquides, généralement employés pour les mesures de pression d'eau, sont d'un emploi très délicat.

De plus, dans les cours d'eau naturels, si l'on utilise la méthode à pression différentielle, l'instrument indiquant la pression devra être placé en un point situé au-dessus du niveau de l'eau. Il peut se produire que la sous-pression engendrée dans les tuyaux de raccordement rende impraticable un tel dispositif.

On peut rattacher à ce qui précède et à dautres imperfections éventuelles le fait que le tube de Pitot ordinaire n'a été employé que d'une manière très restreinte pour les mesures de débit de cours d'eau. On lui préféra des instruments plus compliqués, tels que les micromoulinets, quoiqu'ils soient assujettis à des étalonnages plus fréquents et ne répondent pas aux exigences des mesures près du fond des canaux dans les rivières présentant des transports importants de matériaux, car ces instruments sont trop fragiles pour être exposés à l'action du gravier charrié.

On sait très bien, toutefois, que la branche de l'hydraulique fluviale s'occupant du transport solide demande des renseignements précis sur les mesures, et que c'est à partir de ceux-ci que l'on peut établir une définition satisfaisante de la relation existant entre l'écoulement et le transport solide. Il semble donc avantageux de réunir de plus amples renseignements sur les vitesses d'eau se présentant dans la zone de transport solide le plus intense, où, seul, un dispositif avec tubes de Pitot rudimentaires peut être installé sans risques.

En partant de ce point de vue, le but des recherches élait de déterminer une technique nouvelle de mesure de la pression différentielle, dans laquelle la colonne d'eau dans les tuyaux de raccordement pourrait être remplacée par de l'air, et où l'on pourrait employer des manomètres à un seul liquide ou d'autres instruments indicateurs de pression sensibles.

Dans les paragraphes suivants, nous présenterons une brève description de la technique en cause et de quelques résultats caractéristiques.

Deux cylindres, $\mathrm{L}$ et $\mathrm{H}$ (fig. 1) sont placés le plus près possible des prises de pression - par to be linked by long water-filled flexible pipes, to the filling of which much care must be devoted, if a thorough removal of air is to be assured. Nevertheless, during longer stay or use of the installation, air may gather again in some parts of the apparatus.

Second, measuring troubles arise from oscillatory movements of the waler column in the pipes, provoked by pressure fluctuations in the stream.

Third, two-liquid manometers, mostly" employed for water pressure measurements, are delicate to use.

In natural water courses again, if the differential pressure method is utilized, the pressure indicating instrument has to be placed somewhere above water level. Eventually, the resulling underpressure in the connecting pipes might render such a measuring arrangement unusable.

These and possibly other shorteomings might have been responsible for the fact the simple Pitot-tube has found only a limited use in stream gauging. Instead, more complicated implements, viz. current meters, prevailed, though subject to frequent calibration tests and unserviceable for measuring near the channel bottom in rivers with heavy bed load transport, because too frail to be exposed to drifting pebbles.

It is well known, however, that the branch of fluvial hydraulics dealing with silt transport, is in need of adequate measuring data, upon which a satisfactory definition of the relationship between the flow and the solid material transport could be built. It seems therefore advisable to gather further data on water velocities occurring in the zone of the most intense silt transport, where only a rugged Pitot-type device could be located without risk.

The investigation, starting from this point of view, aimed at a new differential pressure measuring technique, by which the water column in the connecting pipes could be replaced by air, and one-liquid manometers or other sensitive pressure indicating instruments could be employed.

In the next paragraphs a brief description of the developed technique and some pertinent results will be presented.

Two cylinders, L and $\mathrm{H}$ (fig. 1) are located nearest possible to the pressure tappings, e.g. the 
cxemple le tube de Pitot - et raccordés à cellesci par l'intermédiaire d'un robinet réversible $\mathrm{CV}$. La hauteur des cylindres devra être choisie d'après la gamme des différences de pression à mesurer, alors que la section en travers sera déterminée par la précision demandée pour les

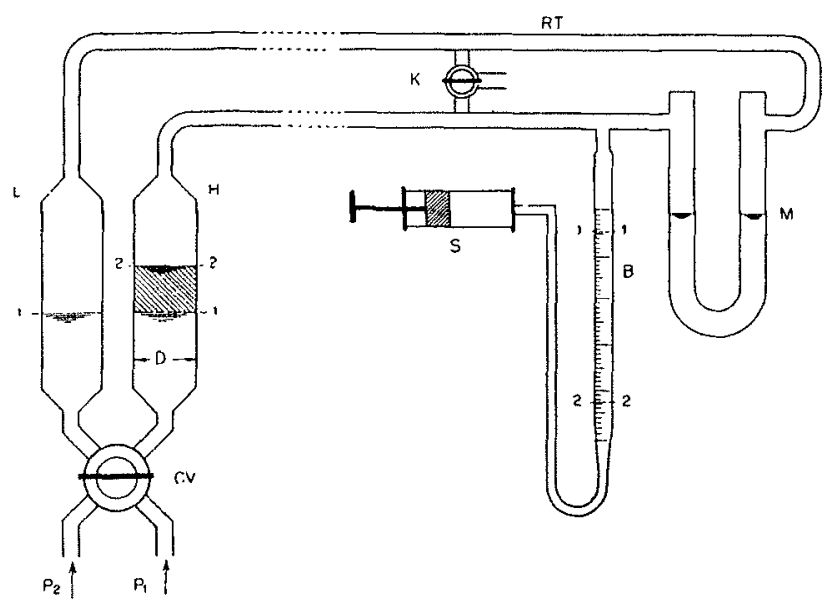

Fig. 1. - Schéna de dispositif

résultats. Partant des prises à l'extrémité supérieure des cylindres, des tuyaux en caoutchouc iront aux deux côtés opposés d'un instrument indicateur de pression différentielle. Un robinet à 3 voies, $K$, permettra, soit la libre communication entre les tuyaux, soit la fermeture de cette communication, soit l'évacuation de l'air contenu dans les tuyaux. De plus, le tuyau de haute pression portera une dérivation sur laquelle on pourra brancher une éprouvette graduée et une seringue.

Les opérations de mesure sont effectuées en deux temps :

Premier temps : le robinet réversible, CV, est mis dans une position telle que les deux cylindres restent en communication avec la prise de basse pression, alors que le robinet à trois voies $K$ reste ouvert pour permettre à l'eau d'entrer dans les cylindres et, à l'air, d'ètre évacué des tuyaux. Pendant ce temps, l'instrument indiquant la pression est calé à la position 0 . Après quelques minutes, lorsque la surface de l'eau dans les cylindres a atteint le niveau de basse pression, on ferme le robinet à trois voies, mais on maintient la communication entre les tuyaux afin de permettre l'égalisation des pressions. Au bout d'un temps assez court, on ferme cette communication. Ceci fait, on tourne le robinet réversible jusqu'à la position dans laquelle un des cylindres reste en communication avec la prise de basse pression, alors que le deuxieme cylindre communique avec la prise de haute pression.

Deuxième temps : l'élévation de l'eau dans le cylindre à haute pression tend à faire dévier
Pitot-tube, and comnected with them by way of a change-over valve, CV. The height of the cylinders should be chosen according to the range of the pressure differences to be measured, whereas the size of the crossection is responsible for the required accuracy of results. From tap-

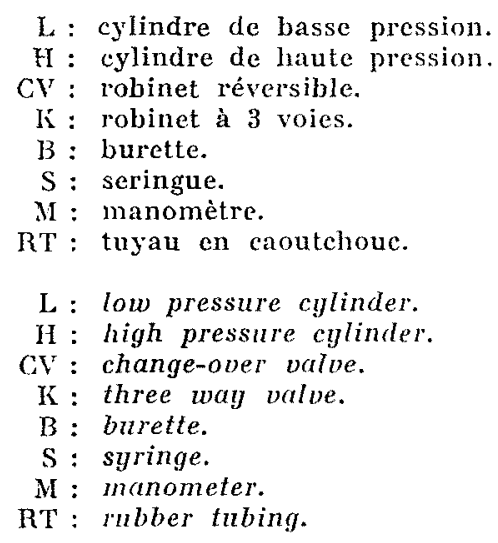

SKETCH OF THE ARIANGEMENT

pings on the upper end of the cylinder's rubber pipes lead to opposite sides of a differential pressure indicating instrument. A three-way valve, $K$, renders possible either free communication between the pipes, or shutting off the communication, or releasing air from the pipes. The high pressure pipe has further a branch to which a graduated buretle and a syringe can be attached.

The measuring procedure is accomplished in two steps.

First step : the change-over valve, $C V$, is put into that position which keeps both cylinders in communication with the low pressure tapping, while the three-way valve, $K$, is left open to allow water entering the cylinders and air escaping from the pipes. Meanwhile, the pressure indicating instrument is set into zero-position. When after some minutes the water surface in the cylinders has risen to the low-pressure level, the three-way valve is closed, but communication hetween the pipes is kept up to permit pressure equalization. After a short time also this connection is closed. This done, the change-over valve is rotated into that position in which one cylinder is kept further in communication with the low pressure tapping, while the second cylinder is to communicate with the high pressure tapping.

SECOND STEP: the rising water in the high pressure cylinder tends to bring the indicating instrument out of zero-reading, which, however, can be reestablished by lowering the liquid surface in the burette. After the indicating in- 
l'instrument de son zéro, lequel, cependant, peut être rétabli en abaissant le niveán de la surface du liquide dans l'éprouvette.

Une fois l'instrument revenu au repos, on fait la lecture de l'éprouvette et la pression différentielle est calcuée par la formule .

$$
\mathrm{P}_{1}-\mathrm{P}_{2}=\mathrm{V} \frac{4 \gamma_{w}}{\mathrm{D}^{2} \pi}
$$

où :

$\mathrm{V}==$ quantité, en $\mathrm{cm}^{3}$, du liquide retiré de l'éprouvelte.

$\mathrm{D}=$ diamètre intérieur, en $\mathrm{cm}$, du cylindre haute pression.

$\gamma_{w}==$ densité spécifique de l'eau, en grammes par $\mathrm{cm}^{3}$.

Etant donné que, pendant les opérations de mesures, la pression d'air dans le système reste la même, il n'y a pas besoin d'incorporer dans la formule des indices de correction pour compression ou dépression d'air.

Il est évident qu'en employant des cylindres de diamètres différents et des instruments ad hoc pour indiquer la pression, on peut élargir à loisir la gamme des mesures de pression différentielle.

On peut appliquer une technique similaire en deux temps pour la détermination d'écoulement par des systèmes à pression différentielle : cylindres, sphères, disques, etc.

Pendant le premier temps, les deux cylindres sont reliés à la même prise de pression, alors que, dans le deuxième temps, les cylindres, quoique à l'origine soumis à des pressions différenles, arrivent finalement à être sous la même pression, à la condition que le système de sonde ait été orienté dans la même direction. Apparemment, la surface du liquide dans l'éprouvette doit rester inchangée dans ce cas.

Lorsque, pour une raison ou une autre, les cylindres sont situés soit trop haut, soit trop bas, par rapport au niveau de basse pression, il faut adjoindre une pompe à air au robinet à 3 voies et, en soumettant l'installation complète a une sous-pression ou à une surpression, on fixera le niveau de la surface de l'eau dans les cylindres à une cote adéquate.

Dans le cas de cylindres opaques, il faudra utiliser soit un indicateur électrique de niveau dans le cylindre de basse pression, soit un manomètre à tube en $U$.

En ce qui concerne la validité des résultats des mesures obtenus par ce procédé, nous devons insister sur le fait que l'air contenu dans l'installation, pendant le deuxième temps, ne doit être soumis ni à des variations de température, ni à des compressions ou dépressions. Par conséquant, on n'utilisera que des tuyaux en caont- strument has come to rest, the reading on the burette is taken and the differential pressure calculated by the formula :

$$
P_{1}-P_{2}=V \frac{4 \gamma_{10}}{D^{2} \pi}
$$

denoting by :

$V=$ the quantity in ccm of liquid redrawn from the burette.

$\mathrm{D}=$ the inner diameter in $\mathrm{cm}$ of the high pressure cylinder.

$\gamma_{w}=$ the specific gravity of water in gramms per ccm.

Since during the measuring procedure the air pressure in the system remains unchanged, correction factors for air compression or depression do not enter the formula.

Obviously, by employing cylinders of various diameters and adequate pressure indicating instruments, differential pressure measurements can be extended over a wide range.

A similar two-step measuring technique is applicable to flow direction determination by differential pressure devices, e.g. cylinders, spheres, discs, etc. During the first operational step both cylinders are in connection with the same pressure tapping, while in the second step, the cylinders, though initially under different pressures, come finally under the equal pressure, if the sounding device has been rotated in the proper direction. Apparently, the liquid surface in the burette must remain unchanged in this case.

Whenever, from one reason or another, the cylinders are positioned either too high or too low regarding the low pressure level, an air pump has to be attached to the threeway" valve and, by applying over-or under-pressure to the whole arrangement, the water surface in the cylinders is put to an appropriate level. With opaque cylinders, in that case, either an electric level indicator in the low pressure cylinder or a U-tube manometer will be necessary.

Concerning the reliability of the measuring results obtained by the described procedure, it may be realized, that the air trapped in the apparatus, during the second step must not be subjected either to thermal changes or to compression and depression. Therefore, only thickwalled rubber hoses should be used as connecting pipes and heat insulation of the air containing parts may be advisable. Owing to the symmetrical arrangement of the apparatus, however, and in view of the short time required for the second operational step, appreciable disturbances from temperature changes are not likely to occur, if the observer avoids touching the air containing parts of the apparatus. 
chouc épais pour Ies raccordements, et il serait préférable de prévoir la protection, contre la chaleur, des parties de l'installation qui contiennent de l'air.

Dans le choix de l'instrument indicateur de pression, on sera guidé principalement par la valeur des pressions différentielles à mesurer. Alors que, pour de fortes pressions différentielles, un manomìtre ordinaire à tube en $U$ sera bien suffisant, pour de petites différences de pression, il sera indispensable de disposer d'un instrument plus sensible, par exemple d'un micromanomètre à bulles. Afin d'obtenir une réponse rapide de ce dernier, il faudra adopter pour le tube capillaire, une longueur comprise entre 50 et $100 \mathrm{~mm}$. Pour des pressions différentielles de $0,01 \mathrm{~mm}$ au moins, on pourra employer avec succès un micromanomètre du type à flotteur. Une description de ces deux micromanomètres a été donnée dans cette revue. ( $L a$ Houille Blanche, $1955, \mathrm{n}^{\circ} 2$.)

Pour l'utilisation à l'extérieur, par exemple pour des mesures dans des cours d'eau naturels, on évitera, dans la plupart des cas, l'emploi de micromanomètres sensibles à liquide, étant donné l'absence de supports rigides pour ces instruments. Après avoir recherché un autre svstème pour mesurer la pression in situ, on adopta finalement le principe de la bobine d'induction, qui donna des résultats prometteurs. Par amplification électronique, on rendit perceptibles les déplacements verticaux d'un petit flotteur faisant fonction de noyau ferrique.

Etant donné la simplicité de la méthode cidessus, il n'y avait aucun empêchement à l'essayer, tout au moins en laboratoire. Les deux robinets spéciaux furent remplacés par deux robinets ordinaires et quelques fers en $\mathbf{T}$. Comme le principal intérêt résidait dans l'application de la méthode à la mesure d'un écoulement de faibles vitesses, les premières mesures furent effectuées dans un canal de laboratoire, de $6 \mathrm{~m}$ de long et $20 \mathrm{~cm}$ de large. La disposition des appareils était en principe celle indiquée sur la figure 1: Le tube de Pitot était du type «impacttrailing $\gg$, constitué par deux tubes de verre d'un diamètre intérieur de $2 \mathrm{~mm}$. Les cylindres étaient en verre et avaient un diamètre de $30 \mathrm{~mm}$. L'instrument qui mesurait la pression était un micromanomètre à bulles à amplification de 90 fois. La pipette remplie d'alcool était graduée en $0,01 \mathrm{~cm}^{3}$, un intervalle sur la graduation correspondant à une hauteur de $0,0133 \mathrm{~mm}$ dans le cylindre. On n'avait prévu aucune protection calorifuge. Afin de vérifier la précision possible de la méthode, on fit 12 lectures successives en deux points : l'un étant à $0,2 \mathrm{~cm}$ et l'autre à $5,85 \mathrm{~cm}$ au-dessus du fond du canal, où la profondeur du courant était de 10,13 cm.
The choice of the pressure indicating instrument is governed mainly by the magnitude of the differential pressures to be measured. Whilc for high pressure diflerences an ordinary U-tube pressure gauge would be quite satisfactory, for small pressure differences a more sensitive instrument will be indispensable, e.g. an air-bubble micromanometer. 'To attain a quick response of the latter, the length of the capillary should be kept between 50 and $100 \mathrm{~mm}$. With differential pressures of $0.01 \mathrm{~mm}$ W.G. or less, the floattype micromanometer may be successfully used. In that case, the diameters of the cylinders should not be less than the diameter of the float vessel. A description of both micromanometers was given in this journal. (La Houille Blanche, $1955, \mathrm{~N}^{\prime 2} 2$.)

For outdoor use, e.g. for measurements in natural streams, the application of sensitive liquid-filled micromanometers will be precluded in most instances at least for the lack of firm supports for these instruments. In search of another. pressure detecting device for outdoor use the inducting coil principle was adopted, which gave promising results. Vertical displacements of a small float serving as a ferric core were mode perceptible by electronic amplification.

In view of the simplicity of the described method, there was no obstacle to testing it, at least in the laboratory. The two valves were replaced by ordinary cocks and some T-pieces. As the main interest lay in the application of the method to measurements of small velocities of flow, the first measurements were tried in a laboratory flume, $6 \mathrm{nl}$ long and $20 \mathrm{~cm}$ wide. The instrumental set-up was in principle that shown in Fig. 1. The Pitot-tube was of the impact-trailing type, arranged of two glass tubes of $2 \mathrm{~mm}$ inner diameter. The cylinders were of glass, and had a diameter of $30 \mathrm{~mm}$. An airbubble micromanometer of 90 times magnification served as the pressure detecting instrument. The alcohol-filled burette had a $0.01 \mathrm{ccm}$ graduation, one scale interval corresponding to the height of $0.0133 \mathrm{~mm}$ in the cylinder. Heat insulation was considered unnecessary. In order to check the attainable precision of the method, 12 successive readings were taken in two points, one being $0.2 \mathrm{~cm}$, and the other $5.85 \mathrm{~cm}$ above the flume bottom, where the depth of flow was $10.13 \mathrm{~cm}$. The arithmetic means af the measured velocities were respectively:

$$
\begin{aligned}
& V_{0.2}=3.55 \pm 0.066 \mathrm{~cm} / \mathrm{s} \text { and } \\
& V_{5.9 .4}=5.84 \pm 0.030 \mathrm{~cm} / \mathrm{s}
\end{aligned}
$$

Measurements by means of the same instrumental arrangement gave further the velocity distribution curve for $\mathfrak{R}_{c}=4,750$, shown in 
Les moyennes arilhmétiques des vitesses mesurées furent respectivement:

$$
\begin{aligned}
& V_{0.2}=3,55 \pm 0,066 \mathrm{~cm} / \mathrm{s} \text { el } \\
& V_{5,85}=5,84 \pm 0,030 \mathrm{~cm} / \mathrm{s}
\end{aligned}
$$

Les mesures effectućes au moyen du même dispositif fournirent en outre la courbe de distribution des vitesses pour $\mathcal{A}_{o}=4.750$, indiquée à la figure 2. Quatre lectures furent faites à chaque point. Pour les conditions d'écoulement laminaire avec $\mathcal{R}_{e}=1.520$, on remplaça les micromanomètres à bulles par un micromanomètre du type flotteur, avec sensibilité de 0,0005 $\mathrm{mm}$ environ.

De plus, au lieu de cylindres, on utilisa deux vases en verre de $10 \mathrm{~cm}$ de diamètre. La courbe de répartition des vitesses ainsi obtenue est représentée dans la figure 2. Etant donné que le tube de Pitot avait été étalonné uniquement en ćcoulement turbulent, les vraies valeurs des vitesses peuvent être quelque peu différentes.

Le dispositif avec microampèremètre à bulles s'est révélé adéquat pour la mesure des pentes sur un modèle fluvial réduit, ainsi que pour la détermination de la direction d'écoulement au moyen d'un disque plat possédant deux ouvertures de pression.

En attendant, on établit les plans de l'appareil à bobine d'induction pour la mesure des pressions, et l'on met au point un matériel pour les mesures sur place.

fig. 2. Four readings were taken in each point. For laminar flow conditions with $\mathfrak{R}_{e}=1,520$ the air-bubble micromanometer was replaced by a float-type micromanometer, sensitive to $R=1520$
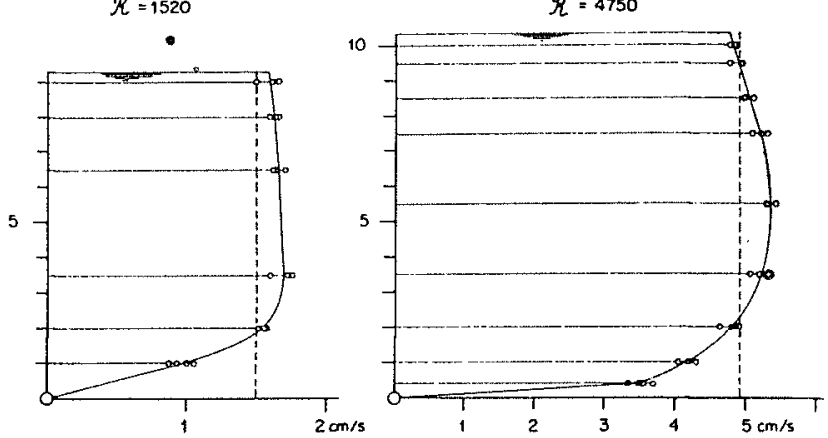

Fig. 2. - Counbes de RËPARTition DES vitesses Velocity distribution curves

$0.0005 \mathrm{~mm}$ W.G. approximately. Further, two glass vessels of $10 \mathrm{~cm}$ diameter were employed instead of the cylinders. The obtained velocity distribution curve is shown in Fig. 2. Since the Pitot-tube had been calibrated in turbulent flow only, the true values of the velocities may be somewhat different.

The arrangement with the air-bubble micromanometer proved adequate for slope measurement in a small scale river model, and also for the determination of flow direction by means of a flat disc with two pressure openings.

Meanwhile, the pressure detecting inductive coil instrument is being elaborated, and an equipment for outdoor use is being developed.

E. Kovacic,

Ljubljana, Yougoslavie.
E, Kovacic,

Ljubljana, Yougoslavie.

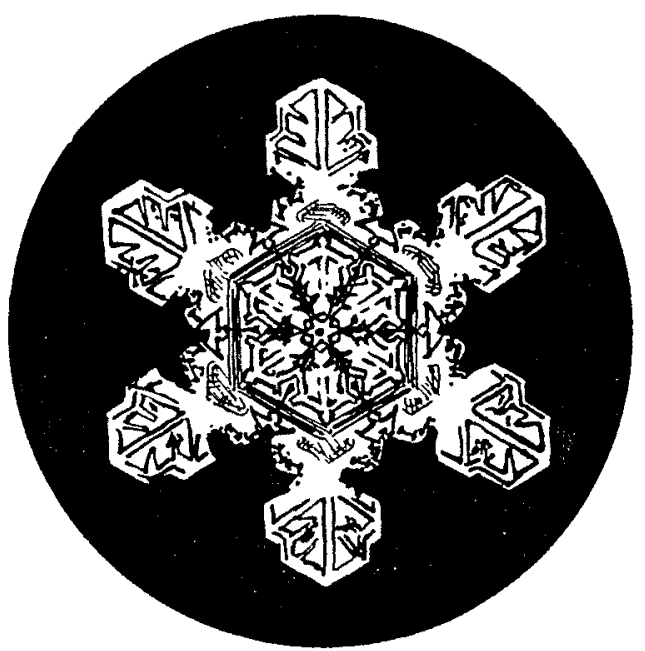

